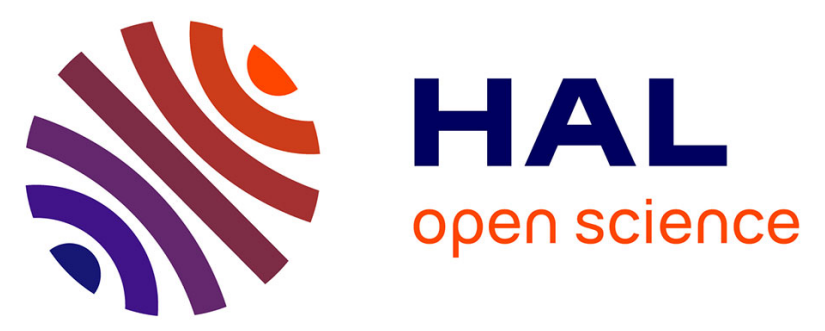

\title{
Managing frame diversity in environmental participatory processes: example from the Fogera woreda in Ethiopia
}

\author{
E. Hassenforder, M. Brugnach, B. Cullen, N. Ferrand, O. Barreteau, K.A.
}

Daniell, J. Pittock

\section{- To cite this version:}

E. Hassenforder, M. Brugnach, B. Cullen, N. Ferrand, O. Barreteau, et al.. Managing frame diversity in environmental participatory processes: example from the Fogera woreda in Ethiopia. Journal of Environmental Management, 2016, 177, pp.288-297. 10.1016/j.jenvman.2016.03.052 . hal-01868951

\section{HAL Id: hal-01868951 \\ https://hal.science/hal-01868951}

Submitted on 6 Sep 2018

HAL is a multi-disciplinary open access archive for the deposit and dissemination of scientific research documents, whether they are published or not. The documents may come from teaching and research institutions in France or abroad, or from public or private research centers.
L'archive ouverte pluridisciplinaire HAL, est destinée au dépôt et à la diffusion de documents scientifiques de niveau recherche, publiés ou non, émanant des établissements d'enseignement et de recherche français ou étrangers, des laboratoires publics ou privés. 


\section{Managing frame diversity in environmental participatory processes Example from the Fogera woreda in Ethiopia}

\section{Emeline HASSENFORDER ${ }^{\mathrm{a}}$}

${ }^{a}$ French National Research Institute of Science and Technology for Environment and Agriculture (IRSTEA), Water Resource Management, Actors and Uses Joint Research Unit (UMR G-EAU), Montpellier, 361 rue J.F. Breton, BP 509534196 Montpellier Cedex 5, France; AgroParisTech; The Australian National University (ANU), Fenner School of Environment and Society, 48 Linnaeus Way, Acton ACT 2601, Australia; emeline.hassenforder@gmail.com

\section{Co-Authors}

\section{Marcela BRUGNACH ${ }^{b}$}

${ }^{\mathrm{b}}$ University of Twente, Water Engineering and Management Group, PO Box 217, 7500 AE Enschede, Drienerlolaan 57522 NB Enschede, The Netherlands, m.f.brugnach@utwente.nl

\section{Beth CULLEN ${ }^{c}$}

${ }^{\mathrm{c}}$ The International Livestock Research Institute (ILRI), P.O. Box 5689 Addis Ababa, Ethiopia, bethselinacullen@gmail.com

\section{Nils FERRAND ${ }^{d}$}

dIRSTEA, G-Eau 361 rue J.F. Breton BP 5095 Cedex 5 Montpellier, France, nils.ferrand@irstea.fr

\section{Olivier BARRETEAU ${ }^{\mathrm{e}}$}

e IRSTEA, G-Eau 361 rue J.F. Breton BP 5095 Cedex 5 Montpellier, France, olivier.barreteau@irstea.fr

\section{Katherine Anne DANIELL ${ }^{f}$}

f The Australian National University (ANU), Centre for European Studies, \#67C, 1 Liversidge St, Acton ACT 2601, Australia, katherine.daniell@anu.edu.au

\section{Jamie PITTOCK ${ }^{\mathrm{g}}$}

${ }^{g}$ The Australian National University, Fenner School of Environment and Society, 48 Linnaeus Way, Acton, ACT, 2601 Australia, jamie.pittock@anu.edu.au 
Author-produced version of the article published in Journal of Environmental Management, 2016, №177, p.288-297.

The original publication is available at http://www.sciencedirect.com

Doi: 10.1016/j.jenvman.2016.03.052

\section{ABSTRACT}

Many participatory processes fail to generate social change and collaborative outcomes. This failure can partly be explained by how divergent stakeholders' frames are handled. This paper builds on the framing and participation literature to explain how facilitators can manage frame diversity and foster collaborative outcomes. It suggests two pragmatic steps: identifying frames and managing frames. The two steps are applied to a participatory process for natural resource management in Fogera, Ethiopia. Effectiveness of facilitators' strategies to manage frame diversity in the Fogera case is discussed. Two main elements challenging effectiveness are identified: counter-strategies used by facilitators and most-powerful stakeholders, and the constraining factors knowledge, champions and frame sponsorship. We argue that these elements need to be taken into account by participatory process facilitators when managing frame diversity.

\section{KEYWORDS}

Africa, ambiguity, collaborative processes, framing, meaning, participation

\section{INTRODUCTION}

\subsection{Diversity of frames in participatory processes}

Participatory processes are increasingly adopted as an approach to promote an integrated and adaptive natural resources management (NRM) (Armitage, 2005; Pahl-Wostl, 2007). Participatory processes may be defined as the practice of consulting and involving relevant stakeholders in the agenda-setting, decisionmaking, and policy-forming activities of organizations or institutions responsible for policy development (based on Rowe and Frewer 2004). Participatory processes generally aim at generating collaborative outcomes while 
Author-produced version of the article published in Journal of Environmental Management, 2016, №177, p.288-297. The original publication is available at http://www.sciencedirect.com

Doi: 10.1016/j.jenvman.2016.03.052

promoting the cognitive, behavioural and institutional changes necessary for self-implementing and sustaining these outcomes over time (Opondo, Sanginga, \& Stroud, 2006).

However, such changes are not easy to attain. They require substantial efforts to develop common objectives, social skills and improve learning. These efforts can easily be stuck in a stalemate. Gray (2004 p.166) argues that "the failure of collaboration can [also] be explained by the divergence of stakeholders' frames about the issues." This stance is hold by several other authors, who have highlighted the importance of different views, understandings or frames in collaborative settings (e.g. Agranoff \& McGuire, 2001; Ansell \& Gash, 2008; Dewulf, Craps, \& Dercon, 2004; Isendahl, Dewulf, \& Pahl-Wostl, 2010; Koppenjan \& Klijn, 2004; Lejano \& Ingram, 2009; Termeer, 2009; van Buuren, 2009). Frames refer to the interpretations that actors give to a situation, affecting the way in which they respond to it (Gray, 2003). For example, a problem of deforestation can be framed as an "insufficient implementation of regulations" by one actor and as a "lack of alternative income generating activities" by another. Framing is the process of labelling a situation as a problem, deciding on its boundaries, what is meant by the problem, what is in and what is out, and eventually discuss its causes and confront those responsible (Felstiner, Abel, \& Sarat, 1980).

Diversity of frames is intrinsic to participatory processes. This diversity can impact the participatory process and its outcomes (Gray, 2004). While diversity is desirable, it can also have negative impacts. It may cause ambiguity in terms of what the problem is or how it should be solved (Brugnach, Dewulf, Henriksen, \& Van der Keur, 2011; Dewulf et al., 2005; Dewulf, Mancero, Cardenas, \& Sucozhanay, 2011; Koppenjan \& Klijn, 2004). When this ambiguity is not taken into account, or when the diverse problem frames are not made transparent, views, values and interests of elites and most powerful participants tend to prevail over the ones of minorities and most disadvantaged stakeholders (Brugnach \& Ingram, 2012; Midgley, 2000). For example, when considering the problem of free grazing ${ }^{1}$ in Ethiopia, one of the arguments of farmers in favour of maintaining communal grazing lands is the use of these areas for religious and social purposes. These perspectives are given no legitimacy by many decision-makers who consider that "technical" arguments such as environmental restoration and soil and water conservation prevail. As a result, decisions made and solutions adopted in the participatory process arena may reflect the interests of some groups only (Ingram \& Stern, 2007) and the

\footnotetext{
${ }^{1}$ Free grazing is when farmers let their cattle roam and feed freely regardless of land ownership.
} 
Author-produced version of the article published in Journal of Environmental Management, 2016, №177, p.288-297.

The original publication is available at http://www.sciencedirect.com

Doi: 10.1016/j.jenvman.2016.03.052

process, rather than leading to collaborative outcomes and social changes, remains elusive and futile (Gray, 2003).

\subsection{The role of facilitators}

Managing frame differences, and the ambiguity that they generate, can be difficult. In participatory processes, this task is usually supported by facilitators. Facilitators are the individuals instigating, designing and/or supporting the participatory process (Kaner, 2014). Facilitators not only need to be able to cope with different interpretations regarding the problem at hand, but they also need to cope with differentials in terms of power and stakes. Commonly, solutions to manage frame differences tend to favour certain frames over others (e.g. technical frames over frames based on lay knowledge). Here, we explore how facilitators can support participatory processes in a way that is inclusive of the diversity of frames and consequent with common collective goals.

\subsection{The need for guidance to facilitators on how to identify and manage frame diversity}

One of the shortcomings of framing studies is that they are often based on communication and discourse analyses (Scheff, 2005), which may be difficult for facilitators to undertake (Alvesson \& Karreman, 2011; Butteriss, Wolfenden, \& Goodridge, 2001). Facilitators are required to translate participants' interactions, discourse or interviews into text and then methodically analyse them before selecting adequate strategies to manage frame diversity. Methods for communication and discourse analysis include, among others, organizational discourse analysis (e.g. Fairhurst and Uhl-Bien 2012), interaction analysis (e.g. Fairhurst 2004; Rogers and Escudero 2004), critical discourse analysis (e.g. Fairclough 2010), conversation analysis (e.g. Pomerantz and Fehr 1997; Psathas 1995) and narrative analysis (e.g. Boje 2001; Gabriel 2004). These methods are weighted towards research applications and empirical developments lag behind (Ospina \& Foldy, 2010). They demand, on the one hand, specialized skills and time from facilitators that may be very difficult to acquire and put in practice, and, on the other hand, a clear approach to cope with divergent perspectives and conflicts that may arise. In short, despite the advances in framing theory, facilitators are still left with the daunting tasks of applying these framing strategies in real life contexts. 
Author-produced version of the article published in Journal of Environmental Management, 2016, №177, p.288-297.

The original publication is available at http://www.sciencedirect.com

Doi: 10.1016/j.jenvman.2016.03.052

Support and guidance to facilitators on how to identify frames and select strategies to manage frame diversity in action while fostering collaborative work, are rare. Practices and know-hows that are adjusted to the concrete needs of facilitators in the doing are, to our knowledge, still missing. In bridging the divide among participants, facilitators need pragmatic guidance in 1 / identifying frames and $2 /$ managing frame diversity in different contexts. The objective of this article is to explain how concretely facilitators can manage frame diversity. We argue that managing frame diversity is required in order to foster the connectedness needed for collaborative work to advance the participatory process mission.

Sections 2 and 3 of the paper suggest two pragmatic steps which can be followed by facilitators to manage frame diversity and foster collaborative outcomes: identifying frames and managing frames. Section 4 illustrates the application of these two steps on one exemplary case: a participatory process for Natural Resource Management (NRM) in Fogera, Ethiopia. Section 5 identifies factors which enabled or constrained the effectiveness of facilitators' strategies to manage frame diversity in the Fogera case. Section 6 summarizes our findings.

\section{IDENTIFYING FRAMES}

We have argued above that in order for participatory process facilitators to foster collaborative work, they need to manage frame diversity. In this section, we start by providing a definition of frames and then provide a methodology which can be used by facilitators to identify frames.

Many disciplines and domains offer definitions of frames and framing, including psychology and decision making theory (e.g. Bateson 1972; Tversky and Kahneman 1981), linguistics and discourse analysis (e.g. Tannen 1993; van Dijk 1977; Dewulf and Bouwen 2012), conflict and negotiation (e.g. Putnam and Holmer 1992; Dewulf et al. 2009; Gray 2004), social movements (e.g. Benford and Snow 2000; Polletta and Ho 2006), 
Author-produced version of the article published in Journal of Environmental Management, 2016, Nㅜ177, p.288-297.

The original publication is available at http://www.sciencedirect.com

Doi: 10.1016/j.jenvman.2016.03.052

communication and media studies (e.g. Chong and Druckman 2007; Entman 1993; Scheufele and Tewksbury 2007), political science and policy studies (e.g. Schon and Rein 1995; Triandafyllidou and Fotiou 1998; Dovers 1995), sociology (e.g. Goffman 1974), problem structuring literature (e.g. Mingers and Rosenhead 2001), and organizational and change management (e.g. Janssens and Steyaert 1999; Lewis 2000; Davidson 2006). In this paper, we adopt a broad definition of frames as interpretations that actors give to a situation, affecting the way in which they respond to it (Gray, 2003).

In a participatory process, various categories of frames co-exist, co-evolve and influence each other. Based on Gray (2004), we consider six frame categories depending on their object, or on what the frame is about, as illustrated in Table 1.

Table 1. Frame categories

\begin{tabular}{|c|c|}
\hline Frame category & Object (what the frame is about) \\
\hline Problem frames & Problems at stake \\
\hline Identity frames & Oneself \\
\hline Characterization frames & Participatory process \\
\hline Process frames & Underlying interests and needs \\
\hline Aspiration frames & Preferred positions or solutions \\
\hline Outcome frames & \\
\hline
\end{tabular}

Problem frames, for instance, are interpretations of a problem, the latter being understood as the topic of concern in the participatory process (based on Dewulf et al. 2009). Participants in participatory processes may hold various interpretations of what the problem actually is. As illustrated earlier, a problem of deforestation for example can be framed as an "insufficient implementation of regulations" by one actor and as a "lack of alternative income generating activities" by another. These interpretations are linked to the way actors see themselves (identity frames), others (characterization frames), the process (process frames), to their 
Author-produced version of the article published in Journal of Environmental Management, 2016, №177, p.288-297. The original publication is available at http://www.sciencedirect.com

Doi: 10.1016/j.jenvman.2016.03.052

underlying interests and needs (aspiration frames) and to their preferred positions or solutions (outcome frames).

Ideally, all participants in a process should be able to identify, acknowledge and challenge all these categories of frames and their effects. However, this cognitive exercise does not occur naturally, and we argue that it is up to facilitators to foster it, by supporting participatory processes in a way that is inclusive of the diversity of frames. Facilitators need to elicit frames (make frames transparent) and inform participants (about other potentially existing frames). In the rest of this paper, we will take the example of problem frames to illustrate how diverse frames can be identified and managed. We suggest that in participatory processes, which aim at addressing specific problems, identifying problem frames is a good start. For a real frame-aware process, a similar procedure can be carried out with all six categories of frames.

Based on Chong and Druckman (2007), we suggest two simple steps which can be used by facilitators to identify frames in participatory processes:

1. Formal identification of frames before or at the early stages of the participatory process,

2. Informal identification of frame evolution throughout the process.

For problem frames for instance, the first step entails the detailed description, at one particular point in time, of the various problem frames which participatory process participants hold. We suggest undertaking this identification before the beginning of the participatory process. This identification can be based on interviews, prior work in the academic and popular literatures, as well as on facilitators' knowledge of the context. It can also be carried out with participants and incorporated as one phase in the participatory process ${ }^{2}$. This formal identification requires the specification of how any particular frame can be identified, for instance by categorizing the universe of words that mark the presence of a frame. For example in the Fogera case presented in section 4, the words "sedimentation", "gully", "soil" or "land degradation", "siltation", "topography" or "soil conservation" (closest English translation from Amharic) marked the presence of the soil

\footnotetext{
${ }^{2}$ However, facilitators need to be aware that participants may not openly divulge their own interpretations of the problem in front of other participants. They may be influenced by a variety of factors, such as the presence of other stakeholders or their role in the group.
} 
Author-produced version of the article published in Journal of Environmental Management, 2016, №177, p.288-297.

The original publication is available at http://www.sciencedirect.com

Doi: 10.1016/j.jenvman.2016.03.052

degradation and erosion problem frame. Coding, i.e. correspondence between presence of these words and their respective frames, can be done digitally or manually. In the Fogera case, coding was made manually, allowing a greater level of detail and made possible thanks to the manageable amount of data sources to be analysed. Two precautions must be taken linked to this initial formal identification of problem frames. First, frame identification may bias facilitator's view of the process and of participants. However, we argue that even when such identification is not made "formally", facilitators hold preconceived views of participants' frames. At least, such identification may reveal facilitators' preconceptions and provide an opportunity to challenge and discuss them. Second, this initial identification does not imply that frames are fixed. It is a "picture" of participants' frames at one point in time. Participants' frames constantly evolve, whether they are managed or not by deliberate strategies.

Once this baseline has been established, facilitators may then identify how frames hereby identified evolve throughout the participatory process. This second step is more "informal" as facilitators may not be able to analyse interactions and discourses thoroughly while the process is ongoing. This informal identification can be based on various methods and sources, depending on available resources and skills. In the Fogera case, the methods used were semi-open interviews of process participants, questionnaires, statements of participants' expectations, videos, participant observation and informal discussions. Selection of interviewees tried to balance conditions in terms of gender, geographical distribution and occupation. In total, 54 interviews and 111 questionnaires were collected before and at various stages of the participatory process.

Section 4.1 illustrates how frame identification can be carried out on a concrete case.

\section{MANAGING FRAMES}

Once facilitators are able to identify frames, they need to be able to manage frames, that is to induce participants to acknowledge their own and others' frames. 
Author-produced version of the article published in Journal of Environmental Management, 2016, №177, p.288-297. The original publication is available at http://www.sciencedirect.com

Doi: 10.1016/j.jenvman.2016.03.052

Following Donnellon, Gray, and Bougon (1986), we argue that in order to support participatory processes in a way that is inclusive of the diversity of frames and commensurate with common collective goals, facilitators do not necessarily need to ensure that all participants in the process hold the same meaning of the problem, or in other terms, that problem frames are aligned. Participants can engage in collective action and produce collaborative outcomes despite their holding very different meanings of the problem at stake. Based on Donnellon, Gray, and Bougon (1986), we suggest that what facilitators must do to support organized action is not necessarily to ensure shared meanings, which can be difficult, but to ensure equifinal meanings, that is a shared repertoire which participants recognize, respond to, and use to interact with one another and to coordinate their actions. The role of facilitators is to structure the development of this shared repertoire.

In the participation and framing literature, several authors have explored strategies to support participatory processes in a way that is inclusive of frame diversity. Some authors look at the influential use of framing effects (e.g. Levin, Schneider, and Gaeth 1998; Chong and Druckman 2007). Framing effects occur when changes in the presentation of a process, a person or a problem, produce changes in participants' opinion, judgments or decisions (Chong \& Druckman, 2007). Levin, Schneider, and Gaeth (1998) identify three different kinds of framing effects which can be influenced: risky choice, attribute and goal framing effects. In the same vein, Dewulf et al. (2011) suggest three key framing processes which can be influenced: selection, focusing and embedding. Chong and Druckman (2007) suggest three psychological mechanisms which can be used to influence participants' frames: the availability, accessibility and applicability of frames. In social movement research, Benford and Snow (2000) show how social movement organizations use a combination of diagnostic, prognostic and motivational framing to mobilize support for their issues. Based on discourse analysis, Dewulf and Bouwen (2012) list five interaction strategies or ways of "doing differences" or dealing with frame differences: frame incorporation, accommodation, disconnection, polarization and reconnection. They compare the five strategies with ways of "dealing with dualities" such as mutual adaptation, splitting the difference, elimination or pruning, selection, escalation or polarization, connection and interpenetration (Bartunek, 2004; Thomas, 1995).

This literature is useful for gaining an understanding of the processes of framing and reframing and how they can be influenced intentionally by facilitators in order to manage frame diversity. However, Levin, Schneider, 
Author-produced version of the article published in Journal of Environmental Management, 2016, №177, p.288-297. The original publication is available at http://www.sciencedirect.com

Doi: 10.1016/j.jenvman.2016.03.052

and Gaeth's (1998), Chong and Druckman's (2007) and Benford and Snow's (2000) strategies are very linked to specific fields (respectively prospect theory, media studies and social movements) and only part of their concepts can be applied to participatory processes. We also argue that Dewulf and Bouwen's (2012) five interaction strategies are very useful for research on frames but can be difficult to implement for facilitators who do not necessarily have the required time or skills to make in-depth discourse analysis while the participatory process is ongoing.

Rather, we suggest to use a more operational and interactional concept developed by Brugnach et al. (2011), who identified five strategies to handle ambiguity: rational problem solving, persuasion, dialogical learning, negotiation and opposition. They define ambiguity as the simultaneous presence of multiple valid, and sometimes conflicting, ways of framing a problem. The rational problem solving strategy "aims at finding solutions to problems by trying to arbitrate the frame differences by invoking scientific evidence" (ibid, p.79). Persuasion implies "convincing others of the meaningfulness of one particular frame of reference" (p.80). Dialogical learning handles frame differences by "engaging all actors in an interactive process of mutual understanding and the creation of shared or connected frames". Negotiation tries to "reach an agreement that is meaningful from different frames" (p.80) while opposition is the imposition of "a particular frame through power strategies" (p.80). Brugnach et al. (2011) suggest that "these strategies can also be used in combination" (p.83). However, they do not describe how. Our analysis builds on their five strategies and aims at bridging this gap by exploring how these five strategies can be used in an operational way by facilitators to manage frame diversity within participatory processes. We illustrate this in section 4 by taking the example of a participatory planning process in the Fogera woreda (district) in Ethiopia.

\section{THE FOGERA PARTICIPATORY PLANNING PROCESS CASE}

This case study is a participatory planning process implemented in the Fogera woreda in Ethiopia, which is part of the largest catchment bordering Lake Tana, the Gumera catchment, at the source of the Blue Nile. The area is $1,030 \mathrm{~km} 2$ in size with a population of about 230,000 people. The participatory process was part of a project 
Author-produced version of the article published in Journal of Environmental Management, 2016, №177, p.288-297.

The original publication is available at http://www.sciencedirect.com

Doi: 10.1016/j.jenvman.2016.03.052

funded by the European Union called AfroMaison ${ }^{3}$. AfroMaison was launched to address the challenges of making integrated NRM in Africa operational. The objective of the participatory planning process was to engage relevant stakeholders in proposing and validating integrated NRM plans and to trigger institutional dynamics to support the implementation of these plans. The process was comprised of six phases developed through a series of participatory workshops (adapted from the Aquastress project ${ }^{4}$, Ferrand, Hare, \& Rougier, 2006):

1. Procedural agreement,

2. Evaluation and identification of a long term common objective,

3. Action proposal,

4. Selection and integration of actions,

5. Test of the plan using a participatory simulation tool (role-playing game), and

6. Implementation plan.

Three workshops took place over ten months, from December 2012 to September 2013. 38 to 52 actors participated in each of the workshops, including regional decision-makers, woreda experts, development agents, non-governmental organizations' representatives, researchers and farmers. Facilitators were eleven researchers from international research institutes, most of them based in Addis Ababa. Two authors of this paper were involved in all phases of the participatory process, where an action research posture was adopted (Checkland \& Holwell, 1998).

\subsection{Identifying frames in the Fogera case}

The Fogera case served as a basis to develop the conceptual framework presented in this paper. Formal identification of problem frames in Fogera was therefore made a posteriori by the two authors of this paper

\footnotetext{
${ }^{3}$ AfroMaison project (2011-2014): "Africa at a meso-scale: Adaptive and integrated tools and strategies for natural resources management" funded by the 7th Framework Program of the European Union, theme " ENV.2010.2.1.1-1" [Integrated management of water and other natural resources in Africa] ${ }^{4}$ AquaStress Integrated Project (2005-2008): "Mitigation of WaterStress through new approaches to Integrating management, technical, economic and institutional instruments" funded by the 6th Framework Program of the European Union, Priority 1.1.6.3 [Global Change and Ecosystems].
} 
Author-produced version of the article published in Journal of Environmental Management, 2016, Nㅜ177, p.288-297.

The original publication is available at http://www.sciencedirect.com

Doi: 10.1016/j.jenvman.2016.03.052

who were also involved in facilitating the participatory process. However, the Fogera case can serve as an example for facilitators to identify frames before or at the early stages of the participatory process. In Fogera, formal problem frame identification was based on participant observation of the early phases of the participatory process, preliminary interviews of process participants, initial questionnaires, statements of participants' expectations, as well as on the results of earlier participatory exercises carried out by facilitators in Fogera (ILRI 2012; Cullen and Adie 2012). Data collected through these methods was then analysed and coded following the methodology for frame identification presented in Section 2.

In order to better understand the ambiguity within specific problem frames, we will focus on one problem described by stakeholders in the Fogera case: free grazing. In Fogera, free grazing has led to land degradation generating erosion, siltation or sedimentation downstream and ultimately reducing crop yields. This problem has been selected as an example because reducing it was chosen by participants as a long term objective to be addressed through the participatory planning process. Table 2 summarizes the various problem frames held on free grazing by process participants.

Table 2. Participants' frames about the free grazing problem in the Fogera case

\begin{tabular}{|c|c|c|}
\hline Participants & Free grazing problem frames & Citations (translated from Amharic) \\
\hline Facilitators & $\begin{array}{l}\text { They outline the interconnections between } \\
\text { soil, agricultural activities and livelihoods. } \\
\text { They look at interventions to balance food } \\
\text { security and natural resource sustainability. }\end{array}$ & $\begin{array}{l}\text { "The environment and the } \\
\text { community are linked. [...] Farmers } \\
\text { and the communities benefit from } \\
\text { the environment, from land and } \\
\text { water" }\end{array}$ \\
\hline $\begin{array}{l}\text { Landless and young } \\
\text { farmers }\end{array}$ & $\begin{array}{l}\text { They agree to stop free grazing if the } \\
\text { communal grazing land is redistributed and } \\
\text { they can get a part of it for cropping } \\
\text {. }\end{array}$ & $\begin{array}{l}\text { "We are interested, if the communal } \\
\text { grazing land changed into cropping } \\
\text { land and landless people can get }\end{array}$ \\
\hline
\end{tabular}

\footnotetext{
5 "Redistribution of the communal grazing land" is a solution frame but is formulated by farmers as an integral part of the free grazing problem frame. This shows the interrelationships among the different categories of frames.
} 
Author-produced version of the article published in Journal of Environmental Management, 2016, №177, p.288-297.

The original publication is available at http://www.sciencedirect.com

Doi: 10.1016/j.jenvman.2016.03.052

\begin{tabular}{|c|c|c|}
\hline & $\begin{array}{l}\text { But they do not want to stop free grazing if } \\
\text { they cannot get a portion of the communal } \\
\text { grazing land because then they would be left } \\
\text { with no land to feed their animals and no } \\
\text { place to pursue their other income- } \\
\text { generating activities (e.g. dung collection, } \\
\text { agricultural production). }\end{array}$ & $\begin{array}{l}\text { "If grazing is restricted, we will face } \\
\text { problems with our animals not } \\
\text { getting enough food and we will not } \\
\text { be able to collect dung for our fuel." }\end{array}$ \\
\hline Poor farmers & $\begin{array}{l}\text { They understand the benefits that they could } \\
\text { get from stopping free grazing and enclosing } \\
\text { communal grazing land. } \\
\text { However, they are constrained by limited } \\
\text { resources (land, money, improved fodder } \\
\text { seeds, material, improved animal breed), } \\
\text { preventing them from destocking and stall- } \\
\text { feeding their livestock. } \\
\text { funerals) or cattle recreation. } \\
\text { They are afraid of the government taking the } \\
\text { it for social and cultural purposes (e.g. } \\
\text { purposes, and not being able to benefit from }\end{array}$ & $\begin{array}{l}\text { "We know cut-and-carry }{ }^{6} \text { is good for } \\
\text { production, increased productivity of } \\
\text { animals for meat and milk" } \\
\text { "For growing fodder in the back yard } \\
\text { it is difficult to get improved seed } \\
\text { and fertilizer. Price is high" } \\
\text { "We think that the government will } \\
\text { take this land if we fence the area" } \\
\text { animal recreation" } \\
\text { "This land is our only place for } \\
\text { important social events." }\end{array}$ \\
\hline Rich farmers & They do not want to stop free grazing. They & "I face problems of feeding all my \\
\hline
\end{tabular}

\footnotetext{
${ }^{6}$ Cut-and-carry is a system where feed is cut and carried from communal areas and/or farms to livestock which are confined to pens on or close to the farm (FAO, 2012).
} 
Author-produced version of the article published in Journal of Environmental Management, 2016, №177, p.288-297.

The original publication is available at http://www.sciencedirect.com

Doi: 10.1016/j.jenvman.2016.03.052

\begin{tabular}{|c|c|c|}
\hline & $\begin{array}{l}\text { have a lot of cattle and therefore are the ones } \\
\text { using the communal grazing land the most. } \\
\text { They are reluctant to sell cattle because it is a } \\
\text { symbol of their wealth. } \\
\text { They have large plots of farmland but often } \\
\text { shrink the communal grazing land to cultivate } \\
\text { it for their own use and fence it. }\end{array}$ & $\begin{array}{l}\text { cattle from my land." } \\
\text { "I face a shortage of feed because } \\
\text { the grazing area is depleted and also } \\
\text { I finished the crop residue. I don't } \\
\text { want to sell some of my animals, } \\
\text { because it is not the best time for } \\
\text { the livestock market. I rather opt to } \\
\text { purchase more feed." } \\
\text { "If the communal grazing land is } \\
\text { enclosed, I might get less share for } \\
\text { my large number of animals" }\end{array}$ \\
\hline $\begin{array}{l}\text { Development } \\
\text { agents (DAs) }\end{array}$ & $\begin{array}{l}\text { They sometimes understand farmers' } \\
\text { constraints which prevent them from } \\
\text { stopping free grazing. But their role is to } \\
\text { convince them to stop this practice and to } \\
\text { train them on alternative management } \\
\text { systems for communal grazing land as well as } \\
\text { alternative feed systems }{ }^{7} \text {. Their discourse } \\
\text { about free grazing mirrors the governmental } \\
\text { one. But their personal opinion about the } \\
\text { problem is mired in their constraints in doing } \\
\text { their jobs: distances, lack of equipment, lack } \\
\text { of skills on specific topics. }\end{array}$ & $\begin{array}{l}\text { "I have taken much training, about } \\
\text { animal husbandries, animal feed and } \\
\text { NRM at zone, woreda and kebele } \\
\text { level. I am the expert; so I can } \\
\text { address farmers' problems" } \\
\text { "If the plan of land administration } \\
\text { was applied; it would be easy to stop } \\
\text { free grazing" } \\
\text { "If the farmer cannot increase the } \\
\text { productivity of his land and animal } \\
\text { performance then it makes me sad" }\end{array}$ \\
\hline
\end{tabular}

${ }^{7}$ This is also a solution frame interconnected with the problem frame (see previous footnote) 
Author-produced version of the article published in Journal of Environmental Management, 2016, №177, p.288-297.

The original publication is available at http://www.sciencedirect.com

Doi: 10.1016/j.jenvman.2016.03.052

\begin{tabular}{|c|c|c|}
\hline & $\begin{array}{l}\text { thing but they sometimes doubt that the } \\
\text { necessary resources will be made available to } \\
\text { implement it (improved seeds, breeds, more } \\
\text { experts). They emphasize on the need to } \\
\text { enforce bye-laws to prevent farmers from } \\
\text { encroaching fenced communal grazing lands. }\end{array}$ & $\begin{array}{l}\text { "Woreda or regional experts promise } \\
\text { something: new technology, } \\
\text { improved breed, artificial } \\
\text { insemination, urea, but, they didn't } \\
\text { supply this technology } \\
\text { and farmers see it as false hope" } \\
\text { "Farmers that have fewer numbers } \\
\text { of livestock resist this idea so } \\
\text { working with police I think can give } \\
\text { more attention to the issue" }\end{array}$ \\
\hline Woreda experts & $\begin{array}{l}\text { They think grazing should be restricted in the } \\
\text { short term. They promote communal grazing } \\
\text { land enclosure because "free grazing" is } \\
\text { understood to be a cause of resource } \\
\text { degradation. They push for interventions to } \\
\text { be implemented to achieve resource } \\
\text { conservation and optimization. } \\
\text { They are subject to pressure from the } \\
\text { regional/zonal authorities to meet targets. } \\
\text { They fear that communities will not agree to } \\
\text { implement the plans because then they will } \\
\text { be made responsible for it by their hierarchy. }\end{array}$ & $\begin{array}{l}\text { "The land should be first forcefully } \\
\text { enclosed by woreda intervention. } \\
\text { Both the farmers and the youth } \\
\text { would be beneficiaries from the } \\
\text { measure taken" } \\
\text { "In the long term I would love to see } \\
\text { farmers stop free grazing and use a } \\
\text { cut-and-carry system" } \\
\text { government wants to do." } \\
\text { "The government wants to stop free } \\
\text { grazing and improve the communal } \\
\text { grazing land. Farmers have }\end{array}$ \\
\hline $\begin{array}{l}\text { Regional } \\
\text { stakeholders }\end{array}$ & $\begin{array}{l}\text { They push policies on communal grazing land } \\
\text { enclosure and rehabilitation to be }\end{array}$ & $\begin{array}{l}\text { “In } 1997 \text { [Ethiopian calendar] there } \\
\text { was a strategy developed to }\end{array}$ \\
\hline
\end{tabular}


Author-produced version of the article published in Journal of Environmental Management, 2016, №177, p.288-297.

The original publication is available at http://www.sciencedirect.com

Doi: 10.1016/j.jenvman.2016.03.052

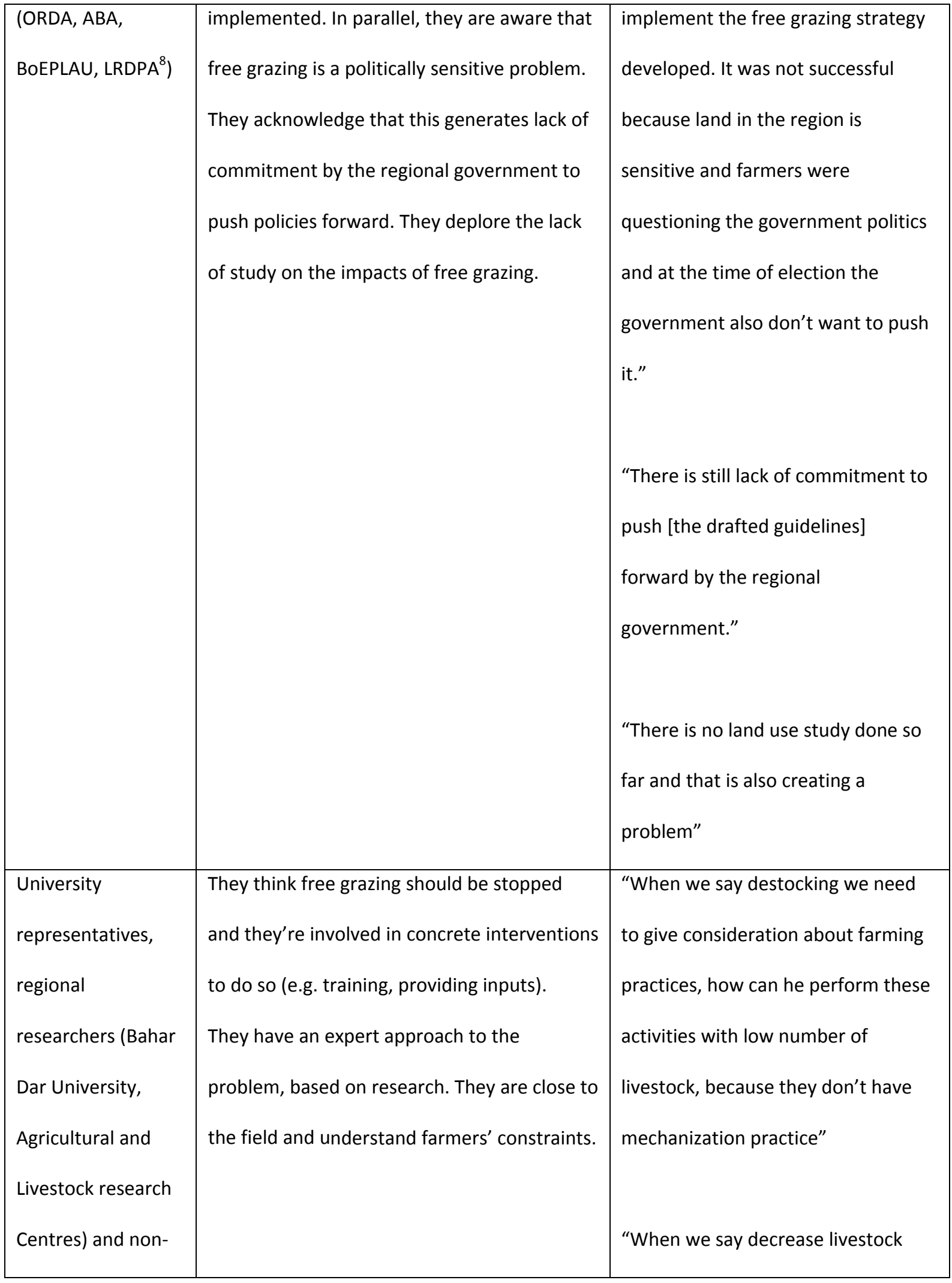

\footnotetext{
${ }^{8}$ ORDA = Organization for Rehabilitation and Development in Amhara $\mathrm{ABA}=$ Abay Basin Authority BoEPLAU = Bureau of Environmental Protection and Land Administration and Use LRDPA = Livestock Resource Development and Protection Agency
} 
Author-produced version of the article published in Journal of Environmental Management, 2016, №177, p.288-297.

The original publication is available at http://www.sciencedirect.com

Doi: 10.1016/j.jenvman.2016.03.052

\begin{tabular}{|l|l|l|}
\hline governmental & numbers [...] first we need to study \\
Wetlands) & & $\begin{array}{l}\text { which area is good for milk or meat } \\
\text { production, see market availability" }\end{array}$ \\
& "I have a mandate to work with \\
communities so I want to contribute. \\
By profession I'm a forester, a NRM \\
expert so when somebody wants to \\
work on that I should take the lead. \\
It is my belief that I can contribute to \\
training and field monitoring with \\
the farmers."
\end{tabular}

Table 2 illustrates that there are major differences in participants' interpretations of the free grazing problem.

This ambiguity results in tensions or even conflicts between certain stakeholders. For example, tension exists between rich farmers, who own a large number of livestock, and poor farmers. During one focus group discussion, when asked about the potential constraints she would face in stopping free grazing, a woman farmer from Kokit kebele mentioned "we can face challenges from wealthy farmers who have more livestock". She adds "we can stop free grazing in a short period of time because we are few people and we have a lot of cattle so if we get together against the rich people we can do it". During the third workshop, a poor farmer said "they [rich farmers] say this feed is enough for us, we don't need to go there [communal grazing land] but the rich farmers were taking all the fodder to their home". Ultimately, these differences and ambiguity can prevent both a common understanding of the free grazing problem, but also the articulation of its solution (Gray, 2004). In consequence, strategies to manage frame differences are required.

\subsection{Managing frames in the Fogera case}


Author-produced version of the article published in Journal of Environmental Management, 2016, №177, p.288-297.

The original publication is available at http://www.sciencedirect.com

Doi: 10.1016/j.jenvman.2016.03.052

Facilitators used a combination of two of the five strategies listed by Brugnach et al. (2011) to manage the diversity of problem frames in the Fogera case: dialogical learning and negotiation.

The main strategy used was dialogical learning. "This strategy handles frame differences through dialogue and learning, engaging actors in an interactive process of communication to create a joint problem definition and an outcome that is beneficial to all of them". According to Brugnach et al. (2011), there are different ways in which dialogical learning can support managing frame diversity: frame-enlargement interventions, exploring one's own frame repertoire and perspective-taking exercises. A combination of these was developed by facilitators throughout the Fogera participatory planning process, as illustrated in Table 3.

Table 3. Tools used by facilitators to manage frame diversity through the dialogical learning strategy in the Fogera participatory process

\begin{tabular}{|l|l|}
\hline \multicolumn{1}{|c|}{ Ways in which dialogical learning can support } & \\
\hline Frame-enlargement interventions & \multicolumn{1}{c|}{ Tools used in the Fogera case } \\
& Comgagement exercises and interviews during the \\
\hline Exploring one's own frame repertoire & workshops, showing the participatory video \\
\hline Perspective-taking exercises & Case studies, narratives \\
& Alternation of group settings \\
\hline
\end{tabular}

In order to give participants opportunities to explore others' problem frames, or in other words to enlarge their own frames, facilitators attempted to bring into the process the widest diversity of frames, including the ones held by stakeholders who were not adequately represented. One challenge they encountered was the fact that selection of the participants in the process was partly made by the Fogera woreda administration and 
Author-produced version of the article published in Journal of Environmental Management, 2016, №177, p.288-297. The original publication is available at http://www.sciencedirect.com

Doi: 10.1016/j.jenvman.2016.03.052

development agents who deliberately selected "model farmers" with similar problem frames related to free grazing (see Cullen et al. 2014 p.267 for discussion). Aware of this bias, facilitators used various tools to include the views of farmers opposed to restricted grazing in the participatory process. For instance, a participatory video had been made as part of a parallel project in an attempt to better involve farmers in the research process (ILRI, 2012). In the participatory video, 12 farmers expressed their views of the constraints and opportunities of restricted grazing. The video was displayed during the first workshop. 11 farmers opposed to restricted grazing were also interviewed by researchers. Their views were used by facilitators to challenge participants' problem frames in the following workshop. Facilitators also managed to have some of these farmers, opposed to restricted grazing, participate in the third workshop. A governmental training campaign required the presence of model farmers and prevented their participation in the workshop. Facilitators used this opportunity to include farmers opposed to restricted grazing. Involving more actors and altering the group composition are mentioned by Dewulf et al. (2011) and Brugnach and Ingram (2012) as one of the process characteristics that are likely to contribute to the connection of frames.

In order for participants to explore their own frames, facilitators used various tools including narratives of case studies and alternation of group settings. For the third workshop, facilitators prepared two narratives: one telling the story of a farmer named Anmut, living in Wajj kebele and one of a development agent named Molla. Both narratives were based on testimonies of real stakeholders but had been modified such that no one could be identified. The objective was to represent the perspectives of these stakeholders and their challenges in order to encourage participants, especially farmers and development agents, to reflect on their own problem frames. The alternation of group settings was another tool used by facilitators to enable participants to explore their own frames. Throughout the participatory planning process, stakeholders were split into different groups working in different rooms. The two main groups were decision-makers and farmers. But others were used such as: upstream, midstream and downstream participants or women farmers, influential farmers and other farmers. Alternation of group settings had three main advantages. Firstly, during group exercises, participants could share their problem frames with others with similar frames in order to explore and better articulate their views. Secondly, this process sometimes served to highlight internal differences within groups which initially may have appeared homogeneous. Thirdly, outcomes of group discussions were 
Author-produced version of the article published in Journal of Environmental Management, 2016, №177, p.288-297. The original publication is available at http://www.sciencedirect.com

Doi: 10.1016/j.jenvman.2016.03.052

presented to other groups and these were key moments in the process when differences in problem frames could be highlighted and discussed.

Two main tools were used for perspective-taking, that is to encourage participant to begin to hear, without judgment, the ways other participants experience the situation: role-playing games (based on Wat-A-Game toolbox: Ferrand et al. 2009; Abrami et al. 2012) and the World Café (Brown, 2005). Two role-playing games were used in Fogera: a "meso" game representing the whole watershed and a local game representing three farming households. Each player is given a role with a specific problem frame on a role card. Various roles were represented: upstream, midstream, downstream and landless farmers in the meso game and rich, medium, poor and landless farmers in the local game. The games allowed the players to understand other ways of framing the problem and to express their views about these. During the local game, decision-makers were asked by facilitators to sit behind farmers and not to intervene. By establishing these interaction rules, facilitators created space for farmers to act freely and to be listened to by decision-makers. Similarly, the World Café allowed a representative of each group of stakeholders (regional, woreda, development agents and farmers) to present his problem frame to other groups and hear their responses. These participatory tools, among others, contribute to the confrontation, discussion and negotiation of problem frames.

The dialogical learning strategy was to a large extent successful. After the presentation of the farmers' plan to decision-makers in the first workshop, one decision-maker mentioned: "we should use the plan of the farmers because they are more practical and closer to reality." Another man from a regional governmental organization said "farmers have done better than us". During these significant moments, participants begin to understand one another and constructive dialogue can take place.

During more conflictual phases of the process, facilitators used a second strategy in order to try and "reach an agreement that is meaningful from different frames" (Brugnach et al. 2011 p.80): negotiation. For example, after the presentation of decision-makers' plan to farmers and vice-versa in the first workshop, tensions started to emerge about the timing of specific activities. At that stage, facilitators suggested to list the points of dissension and discuss them one by one. When, after some time, discussions did not seem to lead to an agreement, facilitators would require participants to vote. For example, decision-makers asked farmers why 
Author-produced version of the article published in Journal of Environmental Management, 2016, №177, p.288-297.

The original publication is available at http://www.sciencedirect.com

Doi: 10.1016/j.jenvman.2016.03.052

they had put compost as a midterm activity rather than short term. One male farmer explained the rationale for it but three other farmers, followed by the rest of the group, highlighted that many farmers were already practicing composting. Following this discussion all farmers agreed to put compost in the short term. In parallel, farmers expressed concerns that road construction should be a priority in order to increase their access to markets, however, decision-makers had put road construction in the long term. One expert from the woreda explained that the government did not have the required resources available in the short term. After a discussion, farmers agreed to contribute to road construction with labour and finance if the government made it a priority. An agreement was reached.

\section{DISCUSSION: FACTORS ENABLING AND CONSTRAINING THE}

\section{EFFECTIVENESS OF STRATEGIES TO MANAGE FRAME DIVERSITY}

In this section, we explore to what extent the strategies used by Fogera facilitators to manage frame diversity were successful. We found that two elements enable or constrain the effectiveness of strategies to manage frame diversity: counter-strategies used unintentionally by facilitators or intentionally by most-powerful stakeholders, and other "constraining factors" such as knowledge, champions and frame sponsorship. These elements are explored in sections 5.1 and 5.2. These factors have to be taken into account by facilitators as part of the problem context when they chose a strategy or combination of strategies to manage frame diversity.

5.1 Counter-strategies used unintentionally by facilitators or intentionally by mostpowerful stakeholders

The development of the dialogical learning and negotiation strategies did not go unchallenged. Facilitators sometimes had difficulties to remain neutral and could not ignore their own knowledge, problem frames and experience. They also faced opposition and persuasion strategies used by the most powerful stakeholders. 
Author-produced version of the article published in Journal of Environmental Management, 2016, №177, p.288-297. The original publication is available at http://www.sciencedirect.com

Doi: 10.1016/j.jenvman.2016.03.052

Being livestock and agricultural experts themselves, facilitators sometimes could not preclude themselves from using a rational problem solving strategy. This strategy "aims at finding solutions to problems by trying to arbitrate the frame differences by invoking scientific evidence" (Brugnach et al. 2011 p.79). Most of the time, facilitators encouraged discussion and learning among participants without expressing their own opinions. However at times, when the discussion was on a topic on which they had expertise, or when participants asked them their opinion, they would mention it. For example during the third workshop, while the group discussed benefits of reducing the number of cattle, one facilitator mentioned:

Jeldu farmers [...] are sending their cattle to other woreda during rainy season and they pay 100 birr per cattle for two months of rainy season. If one farmer has 10 cattle he has to pay 1000 birr for the two months of rainy season [...] for the keeper and his expenses. [Instead] they can decrease the number of livestock as a solution and use this grass [Desho grass that they are growing] to solve their feed shortage problem.

By invoking concrete savings that farmers can benefit from through the reduction of their cattle, the facilitator provides a grounded argument for cattle reduction. Another way in which facilitators used this strategy was by often giving the floor to scientific experts, such as a representative of Bahar Dar University. We do not suggest here that the use of a rational problem solving strategy should be avoided. Facilitators' opinion, especially when facilitators are experts on the problem of concern, is as valuable as other participants. However, facilitators must be conscious of their influence on problem framing. Many authors working on facilitation do not agree with this perspective, arguing that participation should be as "neutral" as possible (e.g. Wong, 2005). We argue that facilitators must take care when changing "hats" (De Bono, 1985) to avoid alienating participants.

The dialogical learning and negotiation strategies were also challenged by opposition strategies used by some participants. Opposition is the imposition of "a particular frame through power strategies" (Brugnach et al. 2011 p.80). Example of this strategy can be found in the discourse of some decision-makers who adopt a "lecturing" tone and use their hierarchical and social position to push their own problem frames forward. For 
Author-produced version of the article published in Journal of Environmental Management, 2016, №177, p.288-297. The original publication is available at http://www.sciencedirect.com

Doi: 10.1016/j.jenvman.2016.03.052

example during the first workshop, when the extension head of the woreda introduced the decision-makers' plan to farmers, he used a very condescending tone. He started by saying "we cannot claim that we know more than farmers", before criticizing farmers: "laziness is not acceptable", "farmers abuse the use of fuel wood, they burn wood until after midnight, they could stop early, go to bed and wake up early to go to the fields" in order to push his own problem frame forward "it is good to suggest land use plans for different types of crops to farmers so that they don't plant whatever they want". Finally he ended by a positive sentence to soften his criticisms "but I don't want to criticize because we're all from the same family". Such opposition strategy was especially used by government representatives during their introduction speeches in workshop openings. Facilitators could react to a certain extent by allowing more time to other stakeholders to react. But they were also bound by the Ethiopian protocol according to which a government official has to open the workshops. This opposition strategy used by the most powerful stakeholders mirrors the persuasion strategies commonly used by the Ethiopian government to convey their ideas about NRM. Awareness-raising campaigns and educational activities are implemented through development agents to teach farmers about the "right" approach to NRM. To a lesser extent, powerful participants also used a rational problem solving strategy. During the third workshop, a representative of the Organization for Rehabilitation and Development of Amhara mentioned "free grazing is decreasing as much as $15 \%$ in Wollo and the livestock in the area is increasing in productivity and generating better income for the farmers". By invoking scientific evidence of the benefits of restricted grazing, he pushes his agenda forward. Opposition strategies were also used by farmers to show their disagreement with the regulations set by the authorities. For example, after the narrative of the farmers' case study, one farmer, approved by others, mentioned "we agree in principle but overall we are reluctant. Fodder development in farmer backyards and communal lands needs to take place first. It is not realistic to reduce cattle numbers in a short period of time. Fodder development and reducing stock needs to be carefully planned and sequenced". These oppositions challenged facilitators' dialogical learning and negotiation strategies.

In a participatory process, all stakeholders consciously or unconsciously employ framing strategies to influence shared meanings (Dewulf \& Bouwen, 2012). In order to manage frame diversity and ultimately foster collective outcomes, facilitators need to be aware of the various frames, to reveal them in the social sphere and bring them into discussion. 
Author-produced version of the article published in Journal of Environmental Management, 2016, №177, p.288-297. The original publication is available at http://www.sciencedirect.com

Doi: 10.1016/j.jenvman.2016.03.052

\subsection{Other constraining factors impacting the effectiveness of strategies to manage}

\section{frame diversity}

Several authors have identified "constraining factors" which impacted on the effectiveness of strategies to manage frame diversity in their case studies (e.g. Chong and Druckman 2007; Bartlett 1932; Carragee and Roefs 2004). In the Fogera case, three main factors seem to have influenced the dialogical learning and negotiation strategies used by facilitators. These are: knowledge, champions and the agenda followed by some of the stakeholders, or "frame sponsorship".

The knowledge that participants have of the problem, but also of other frame objects - such as the constraints of other actors, the possible solutions to stop free grazing or about participatory processes - shape their frames. Such knowledge impacts their understanding of other participants' frames and ultimately may influence the effectiveness of the facilitators' strategies to manage frame diversity. In Fogera, participants originating from communities where trainings had been carried out about free grazing by development agents or NGOs had different visions of the problem. Often, they understood the benefits of using cut-and-carry or other alternative systems to free grazing. This was even truer when practical demonstrations had been made, and where they could see the benefits on fellow farmers. Brugnach and Ingram (2012 p.61) cite "ambiguity is often the result of unrecognized contextual, methodological and substantive differences among knowledge systems". Through knowledge sharing, facilitators can therefore increase the effectiveness of their strategies to manage frame diversity. However, knowledge can also easily be used towards negative ends, for example by elites or other actors' groups, as has been demonstrated widely in the communication framing literature (e.g. Brewer, Graf, and Willnat 2003). Brugnach and Ingram (2012) recommend considering knowledge as a coproduction process by recognizing interdependencies, building good relationships and creating the decision space that supports collaboration. For this to happen, spaces need to be created within which multiple forms of knowledge can be expressed and shared. 
Author-produced version of the article published in Journal of Environmental Management, 2016, №177, p.288-297. The original publication is available at http://www.sciencedirect.com

Doi: 10.1016/j.jenvman.2016.03.052

A second factor which played a role in the Fogera case is the intervention of champions. As highlighted by Gray (2004), reframing "depends on the ability of at least some of the actors to inquire into the intentions and meanings of other actors". In Fogera, the role of champions in problem framing and reframing was noticeable. Five decision-makers in particular had a bridging role. The majority participated in all three workshops. Their position - most worked both with decision-makers and farmers - provided them with a unique understanding of others' frames and constraints. During the first workshop, when several decision-makers challenged farmers' plan, one champion from Bahar Dar University emphasized that, according to him, and contrary to what other decision-makers argued, zero grazing was impossible to achieve in the short term. To support his argument, he talked about his experience with communities and the constraints faced by farmers on the ground. Thanks to their legitimacy and credibility, champions were able to convince other decision-makers of the relevance of the farmers' frames, even when facilitators had failed to do so. It is useful for facilitators to identify and invite a few champions when engaging a participatory process, as they will likely increase the effectiveness of the strategies to manage frame diversity, along with the overall success of the process (Gallagher, 2009).

Finally, the agenda pursued by the various stakeholders can impact their frames. Understanding stakeholders' agendas requires investigating which organization they work for, what is their role within the organization and what interests they came to defend. This is not necessarily always easy to do. Stakeholders may have multiple agendas, some of which they may be reluctant to express openly. Carragee and Roefs (2004) call this agenda "frame sponsorship". In the Fogera case for instance, facilitators were influenced both by the project and their organization's agenda. The participatory process was developed in the frame of two projects: AfroMaison, led by the International Water Management Institute (IWMI) and the Nile Basin Development Challenge ${ }^{9}$ led by the International Livestock Research Institute (ILRI). Facilitators belonged to one or the other organization. Some worked for IWMI whose mission is "to provide evidence-based solutions to sustainably manage water and land resources for food security, people's livelihoods and the environment" (IWMI, 2015). Others worked for ILRI whose mission is "ensuring better lives through livestock" (ILRI, 2015). Most of the time, the agenda of these two projects and organisations overlapped. But at times, they were conflicting, which led facilitators to

\footnotetext{
${ }^{9}$ The Nile Basin Development Challenge (NBDC) (2010-2013): "Rainwater management for resilient livelihoods" funded by the Challenge Program on Water and Food (CPWF) of the Consortium of International Agricultural Research Centers (CGIAR).
} 
Author-produced version of the article published in Journal of Environmental Management, 2016, №177, p.288-297.

The original publication is available at http://www.sciencedirect.com

Doi: 10.1016/j.jenvman.2016.03.052

defend different interests. This has been previously described in the literature as "co-engineering negotiation", where differences in frames at the level of the process facilitators' create a second level of conflict and a need for negotiation and learning (Daniell et al., 2010). These types of negotiations are also referred to as a "shadow negotiations" in the business and negotiation literature (Kolb \& Williams, 2001; Lewicki, Saunders, \& Barry, 2006). At the end of the first workshop, a disagreement emerged among some facilitators regarding framing of the problem. Below is an abstract of the discussion between two facilitators (F1 and F2).

- F1: Even though F2 suggested to focus the next workshop on free grazing, the stakeholders said they liked the fact to have integrated strategies.

- F2: but in terms of strategy, it's hard to implement.

- F1: AfroMaison project is about producing integrated plans and then assess how the implementation goes.

F2, working for ILRI, sustained that in the following workshop the plans should be reframed to focus on free grazing in order to increase their implementability. F1, working for IWMI, argued for a broader and more integrated approach between land and water and reminded AfroMaison's objective. Unconsciously, these arguments followed the facilitators' respective organizations' and projects' missions. Finally, it was decided to reframe the plans on one problem decided by the participants.

Many other factors can play a role in the effectiveness of the strategies used, including past experiences (Bartlett, 1932), political and cultural opportunities and constraints (Benford \& Snow, 2000) or stakeholders' backgrounds, societal positions and values and beliefs (Brugnach \& Ingram, 2012). There is a vast potential for further research in that domain.

\section{CONCLUSION}

The research question of this paper was: how can facilitators manage frame diversity in order to foster the connectedness needed for collaborative work to advance the participatory process mission? We highlighted 
Author-produced version of the article published in Journal of Environmental Management, 2016, №177, p.288-297. The original publication is available at http://www.sciencedirect.com

Doi: 10.1016/j.jenvman.2016.03.052

the need for facilitators to start by identifying the various frames in the participatory process. We suggested this identification to be made in two steps: a formal identification of frames before or during early stages of the participatory process and an informal identification of frames' evolution throughout the process. Based on Brugnach et al. (2011), we then suggested five strategies which could be used by facilitators to manage frame diversity and foster collaborative outcomes: rational problem solving, persuasion, dialogical learning, negotiation and opposition. We illustrated how frames could be identified and managed through the example of a participatory process in Fogera, Ethiopia. We then discussed the effectiveness of facilitators' strategies to manage frame diversity in the Fogera case. We found that two elements challenged the effectiveness of facilitators' strategies: counter-strategies used unintentionally by facilitators or intentionally by most-powerful stakeholders, and other "constraining factors" such as knowledge, champions and frame sponsorship. We suggest that these three elements need to be taken into account by participatory process facilitators when selecting a strategy to manage frame diversity. The methodology suggested in this paper can be extended to other cases. The core objective of this paper was indeed to provide pragmatic guidance to facilitators in identifying frames and managing frame diversity in different contexts. However, the elements which challenged the effectiveness of facilitators' strategies in the Fogera case, may differ in another context. Further research would be needed to test whether these elements also challenge the effectiveness of facilitators' strategies to manage frame diversity in other cases.

\section{ACKNOWLEDGEMENTS}

The authors thank the Ethiopian facilitators for their support, especially Aberra Adie, Elias Damtew, Liza Debevec, Girma Hundessa, Zelalem Lema, Mulugeta Lemenih, Gerba Leta, Birhanu Megersa Lenjiso, Getachew Molla, Tsehay Regassa, and Birhanu Zemadim. The authors also thank all the participants to the participatory planning process and all the interviewees without whom this research could not have unfolded.

This work was supported by the AfroMaison European Seventh Framework Programme (FP7) research project, the Consultative Group on International Agricultural Research (CGIAR) Challenge program on Water and Food as part of the Nile Basin Development Challenge (NBDC), the UNESCO Chair in Water Economics and Transboundary Water Governance and the Fenner School of Environment \& Society from the Australian 
Author-produced version of the article published in Journal of Environmental Management, 2016, №177, p.288-297.

The original publication is available at http://www.sciencedirect.com

Doi: 10.1016/j.jenvman.2016.03.052

National University (ANU). The donors did not have any direct role in study design, in the collection, analysis

and interpretation of data, in the writing of the report; or in the decision to submit the article for publication.

The views expressed are those of the authors and do not reflect the official position of the European

Commission, CGIAR, UNESCO or the ANU.

\section{DisCLOSURE STATEMENT}

The authors declare that they have no conflict of interest.

All procedures performed in studies involving human participants were in accordance with the ethical standards of the institutional and/or national research committee and with the European Commission 7th Framework Program ethical standards (2013):

http://ec.europa.eu/research/participants/data/ref/fp7/89888/ethics-for-researchers en.pdf. Informed consent was obtained from all individual participants included in the study. Additional informed consent was obtained from all individual participants for whom identifying information is included in this article.

\section{REFERENCES}

Abrami, G., Ferrand, N., Morardet, S., Murgue, C., Popova, A., De Fooij, H., ... Aquae-Gaudi, W. (2012). Wat-AGame, a toolkit for building role-playing games about integrated water management. In R. Seppelt, A. A. Voinov, S. Lange, \& D. Bankamp (Eds.), iEMSs Sixth Biennial Meeting. Leipzig, Germany. Retrieved from http://www.iemss.org/society/index.php/iemss-2012-proceedings

Agranoff, R., \& McGuire, M. (2001). Big Questions in Public Network Management Research. Journal of Public Administration Research and Theory, 11(3), 295-326. Retrieved from http://jpart.oxfordjournals.org/content/11/3/295.abstract

Alvesson, M., \& Karreman, D. (2011). Decolonializing discourse: Critical reflections on organizational discourse analysis. Human Relations, 64(9), 1121-1146.

Ansell, C., \& Gash, A. (2008). Collaborative governance in theory and practice. Journal of Public Administration Research and Theory, 18(4), 543-571.

Armitage, D. (2005). Adaptive capacity and community-based natural resource management. Environmental Management, 35(6), 703-715. 
Author-produced version of the article published in Journal of Environmental Management, 2016, №177, p.288-297. The original publication is available at http://www.sciencedirect.com

Doi: 10.1016/j.jenvman.2016.03.052

Bartlett, F. C. (1932). Remembering : A Study in Experimental and Social Psychology. (F. C. Bartlett, Ed.). Cambridge, England: Cambridge University Press. doi:10.1111/j.2044-8279.1933.tb02913.x

Bartunek, J. M. (2004). The importance of Contradictions in Social Intervention. Intervention Research, 1(1), 103-113. Retrieved from http://proxy.bc.edu/login?url=http://search.ebscohost.com/login.aspx?direct=true\&db=bth\&AN=16260 257\&site=bsi-live

Bateson, G. (1972). Steps to an Ecology of Mind. New York: Ballantine.

Benford, R. D., \& Snow, D. A. (2000). Framing Processes and Social Movements: An Overview and Assessment. Annual Review of Sociology, 26(1), 611-639.

Boje, D. M. (2001). Narrative Methods for Organizational \& Communication Research. Thousand Oaks, CA: Sage.

Brewer, P. R., Graf, J., \& Willnat, L. (2003). Priming or Framing: Media Influence on Attitudes Toward Foreign Countries. International Communication Gazette, 65(6), 493-508.

Brown, J. (2005). The World Cafe': Shaping Our Futures Through Conversations that Matter. San Francisco, CA: Berrett-Koehler.

Brugnach, M., Dewulf, A., Henriksen, H. J., \& Van der Keur, P. (2011). More is not always better: Coping with ambiguity in natural resources management. Journal of Environmental Management, 92(1), 78-84.

Brugnach, M., \& Ingram, H. (2012). Ambiguity: The challenge of knowing and deciding together. Environmental Science and Policy, 15(1), 60-71.

Butteriss, C., Wolfenden, J. A. J., \& Goodridge, A. P. (2001). Discourse Analysis: a Technique to Assist Conflict Management in Environmental Policy Development. Australasian Journal of Environmental Management, 8(1), 48-58. doi:10.1080/14486563.2001.10648512

Carragee, K. M., \& Roefs, W. (2004). The neglect of power in recent framing research. Journal of Communication, 54(2), 214-233.

Checkland, P., \& Holwell, S. (1998). Action research: its nature and validity. Systemic Practice and Action Research, 11(1), 9-21.

Chong, D., \& Druckman, J. N. (2007). Framing Theory. Annual Review of Political Science, 10(1), 103-126.

Cullen, B., Tucker, J., Snyder, K., Lema, Z., \& Duncan, A. (2014). An analysis of power dynamics within innovation platforms for natural resource management. Innovation and Development, 4(2), 259-275. doi:10.1080/2157930X.2014.921274

Daniell, K. A., White, I., Ferrand, N., Ribarova, I. S., Coad, P., Rougier, J.-E., ... Burn, S. (2010). Co-engineering participatory water management processes: Theory and insights from Australian and Bulgarian interventions. Ecology and Society, 15(4), 11.

Davidson, E. (2006). A Technological Frames Perspective on Information Technology and Organizational Change. The Journal of Applied Behavioral Science, 42(1), 23-39. doi:10.1177/0021886305285126

De Bono, E. (1985). Six Thinking Hats: An Essential Approach to Business Management. New York, NY: Little, Brown, \& Company. 
Author-produced version of the article published in Journal of Environmental Management, 2016, №177, p.288-297. The original publication is available at http://www.sciencedirect.com Doi: 10.1016/j.jenvman.2016.03.052

Dewulf, A., \& Bouwen, R. (2012). Issue Framing in Conversations for Change: Discursive Interaction Strategies for "Doing Differences." The Journal of Applied Behavioral Science, 48(2), 168-193.

Dewulf, A., Craps, M., \& Dercon, G. (2004). How issues get framed and reframed when different communities meet: a multi-level analysis of a collaborative soil conservation initiative in the Ecuadorian Andes. Journal of Community and Applied Social Psychology, 14(3), 177-192.

Dewulf, A., Gray, B., Putnam, L., Aarts, N., Lewicki, R., Bouwen, R., \& van Woerkum, C. (2005). Disentangling approaches to framing: mapping the terrain. IACM 18th Annual Conference. Retrieved from http://papers.ssrn.com/sol3/Delivery.cfm?abstractid=728203

Dewulf, A., Gray, B., Putnam, L., Lewicki, R., Aarts, N., Bouwen, R., \& van Woerkum, C. (2009). Disentangling approaches to framing in conflict and negotiation research: A meta-paradigmatic perspective. Human Relations, 62(2), 155-193.

Dewulf, A., Mancero, M., Cardenas, G., \& Sucozhanay, D. (2011). Fragmentation and connection of frames in collaborative water governance: a case study of river catchment management in Southern Ecuador. International Review of Administrative Sciences, 77(1), 50-75. doi:10.1177/0020852310390108

Donnellon, A., Gray, B., \& Bougon, M. G. (1986). Communication, Meaning, and Organized Action. Administrative Science Quarterly, 31(1), 43-55.

Dovers, S. R. (1995). A framework for scaling and framing policy problems in sustainability. Ecological Economics, 12(2), 93-106.

Entman, R. M. (1993). Framing: Toward Clarification of a Fractured Paradigm. Journal of Communication, 43(4), 51-58. Retrieved from http://doi.wiley.com/10.1111/j.1460-2466.1993.tb01304.x

Fairclough, N. (2010). Critical Discourse Analysis The critical Study of Language (2nd ed.). London, England: Routledge.

Fairhurst, G. T. (2004). Textuality and Agency in Interaction Analysis. Organization, 11(3), 335-353.

Fairhurst, G. T., \& Uhl-Bien, M. (2012). Organizational discourse analysis (ODA): Examining leadership as a relational process. Leadership Quarterly, 23(6), 1043-1062.

FAO. (2012). Mixed Systems: Cut and Carry. Livestock, Environment and Development Initiative (LEAD) toolbox. Retrieved April 29, 2015, from http://www.fao.org/ag/againfo/programmes/en/lead/toolbox/Mixed1/MSys3CC.htm

Felstiner, W. L. F., Abel, R. L., \& Sarat, A. (1980). The Emergence and Transformation of Disputes: Naming, Blaming, Claiming. Law \& Society Review, 15(3/4), 631-654. Retrieved from http://www.jstor.org/stable/3053505

Ferrand, N., Farolfi, S., Abrami, G., \& Du Toit, D. (2009). WAT-A-GAME: sharing water and policies in your own basin. In "Learn to Game, Game to Learn", ISAGA 40th Annual Conference. Singapore.

Ferrand, N., Hare, M., \& Rougier, J.-E. (2006). Iskar Test Site Option Description Living with Flood and Drought. Methodological document to the Iskar Test Site, AquaStress IP, FP6, Europe. Brussels, Belgium.

Gabriel, Y. (2004). Narratives, stories and texts. In D. Grant, C. Hardy, C. Oswick, \& L. Putnam (Eds.), The Sage Handbook of Organizational Discourse (pp. 61-77). London, England: Sage. 
Author-produced version of the article published in Journal of Environmental Management, 2016, №177, p.288-297. The original publication is available at http://www.sciencedirect.com Doi: 10.1016/j.jenvman.2016.03.052

Gallagher, D. R. (2009). Advocates for environmental justice: the role of the champion in public participation implementation. Local Environment, 14(10), 905-916.

Goffman, E. (1974). Frame analysis: An essay on the organization of experience. Cambridge, MA: Harvard University Press.

Gray, B. (2003). Framing of Environmental Disputes. In R. J. Lewicki, B. Gray, \& M. Elliott (Eds.), Making Sense of Intractable Environmental Conflicts: Concepts and Cases (pp. 11-34). Washington, DC: Island Press.

Gray, B. (2004). Strong opposition: Frame-based resistance to collaboration. Journal of Community and Applied Social Psychology, 14(3), 166-176.

ILRI. (2012). A Rope to Tie A Lion. Ethiopia. Retrieved from http://www.youtube.com/watch?v=7SSOm1hsCsE

ILRI. (2015). Vision, mission and strategy. Retrieved January 15, 2015, from https://www.ilri.org/mission

Ingram, H., \& Stern, P. (2007). Research and Networks for Decision Support in the NOAA Sectoral Applications Research Program. Washington, DC: National Academies Press.

Isendahl, N., Dewulf, A., \& Pahl-Wostl, C. (2010). Making framing of uncertainty in water management practice explicit by using a participant-structured approach. Journal of Environmental Management, 91(4), 844851.

IWMI. (2015). About IWMI. Retrieved January 15, 2015, from http://www.iwmi.cgiar.org/about/overview/

Janssens, M., \& Steyaert, C. (1999). The world in two and a third way out? The concept of duality in organization theory and practice. Scandinavian Journal of Management, 15(1), 121-139.

Kaner, S. (2014). Facilitator's Guide to Participatory Decision-Making (3rd ed.). San Francisco, CA: Jossey-Bass.

Kolb, D., \& Williams, J. (2001). The shadow negotiation: How women can master the hidden agendas that determine bargaining success. (D. Kolb \& J. Williams, Eds.). New York, NY: Simon and Schuster.

Koppenjan, J., \& Klijn, E.-H. (2004). Managing uncertainties in networks: a network approach to problem solving and decision making. Erasmus. London, England: Routledge. Retrieved from http://scholar.google.nl/scholar?hl=en\&q=Managing+uncertainties+in+networks:+Public+private+contro versies.\&btnG=Search\&as_sdt=0,5\&as_ylo=\&as_vis=0\#1

Lejano, R. P., \& Ingram, H. (2009). Collaborative networks and new ways of knowing. Environmental Science \& Policy, 12(6), 653-662. doi:10.1016/j.envsci.2008.09.005

Levin, I. P., Schneider, S. I., \& Gaeth, G. J. (1998). All frames are not created equal: A typology and critical analysis of framing effects. Organisational Behaviour and Human Decision Processes, 76(2), 149-188.

Lewicki, R. J., Saunders, D. M., \& Barry, B. (2006). Negotiation. New York, NY: McGraw-Hill International.

Lewis, M. W. (2000). Exploring paradox: Toward a more comprehensive guide. Academy of Management Review, 25(4), 760-776.

Midgley, G. (2000). Systemic Intervention: Philosophy, Methodology, and Practice. New York, NY: Kluwer Academic / Plenum.

Mingers, J., \& Rosenhead, J. (2001). Rational Analysis for a Problematic World Revisited. Chichester: John Wiley and Sons. 
Author-produced version of the article published in Journal of Environmental Management, 2016, №177, p.288-297. The original publication is available at http://www.sciencedirect.com Doi: 10.1016/j.jenvman.2016.03.052

Opondo, C., Sanginga, P., \& Stroud, A. (2006). Monitoring the Outcomes of Participatory Research in Natural Resources Management, Experiences of the African Highlands Initiative. Kampala, Uganda. Retrieved from http://www.worldagroforestry.org/programmes/african-highlands/pdfs/wps/ahiwp_02.pdf

Ospina, S., \& Foldy, E. (2010). Building bridges from the margins: The work of leadership in social change organizations. The Leadership Quarterly, 21(2), 292-307. doi:10.1016/j.leaqua.2010.01.008

Pahl-Wostl, C. (2007). The implications of complexity for integrated resources management. Environmental Modelling and Software, 22(5), 561-569.

Polletta, F., \& Ho, M. K. (2006). Frames and their consequences. In R. E. Gooden \& C. Tilly (Eds.), The Oxford Handbook of Contextual Political Studies (pp. 187-210). Oxford, UK: Oxford University Press.

Pomerantz, A., \& Fehr, B. J. (1997). Conversation Analysis: an Approach To The Study of Social Action as Sense Making Practices. In T. A. Van Dijk (Ed.), Discourse as social interaction (pp. 64-91). Thousand Oaks, CA: Sage.

Psathas, G. (1995). Conversation analysis: The study of talk-in-interaction. (S. McElroy, Ed.). Thousand Oaks, CA: Sage.

Putnam, L., \& Holmer, M. (1992). Framing, Reframing and Issue Development. In L. Putnam \& M. E. Roloff (Eds.), Communication \& Negotiation (pp. 128-155). Newbury Park, CA: Sage.

Rogers, L. E., \& Escudero, V. (2004). Relational communication: An interactional perspective to the study of process and form. (L. E. Rogers \& V. Escudero, Eds.). Mahwah, NJ: Erlbaum.

Rowe, G., \& Frewer, L. J. (2004). Evaluating Public-Participation Exercises: A Research Agenda. Science Technology And Human Values, 29(4), 512-556. Retrieved from http://sth.sagepub.com/cgi/doi/10.1177/0162243903259197

Scheff, T. J. (2005). The structure of context: Deciphering frame analysis. Sociological Theory, 23(4), 368-385.

Scheufele, D. A., \& Tewksbury, D. (2007). Framing, agenda setting, and priming: The evolution of three media effects models. Journal of Communication, 57(1), 9-20.

Schon, D. A., \& Rein, M. (1995). Frame Reflection: Toward The Resolution Of Intractrable Policy Controversies. Basic Books. New York: Basic Books.

Tannen, D. (1993). Framing in discourse. (D. Tannen, Ed.). New York, Oxford: Oxford University Press.

Termeer, C. J. A. M. (2009). Barriers To New Modes Of Horizontal Governance. Public Management Review, 11(3), 299-316.

Thomas, R. J. (1995). A diversity framework. In M. Chemers, S. Oskamp, \& M. Constanzo (Eds.), Diversity in organizations: New perspectives for a changing workplace (pp. 245-264). London, England: Sage.

Triandafyllidou, A., \& Fotiou, A. (1998). Sustainability and Modernity in the European Union: A Frame Theory Approach to Policy-Making. Sociological Research Online, 3(1).

Tversky, A., \& Kahneman, D. (1981). The framing of decisions and the psychology of choice. Science, 211(4481), 453-458. 
Author-produced version of the article published in Journal of Environmental Management, 2016, №177, p.288-297. The original publication is available at http://www.sciencedirect.com

Doi: 10.1016/j.jenvman.2016.03.052

Van Buuren, A. (2009). Knowledge for Governance, Governance of Knowledge: Inclusive Knowledge Management in Collaborative Governance Processes. International Public Management Journal, 12(2), 208-235.

Van Dijk, T. A. (1977). Semantic macro-structures and knowledge frames in discourse comprehension. In Cognitive processes in comprehension (pp. 3-32). Hillsdate, NJ: Lawrence Erlbaum Associates.

Wong, P. (2005). Creating a positive participatory climate: a meaning-centered counselling perspective. In S. Schuman (Ed.), The IAF handbook of group facilitation: best practices from the leading organization in facilitation (pp. 171-190). San Francisco, CA: Jossey-Bass. 